\title{
Human Issues in Horticulture
}

\author{
Paula Diane Relf \\ Department of Horticulture, Virginia Polytechnic and State University, Blacksburg, VA 24061-0327 \\ Virginia I. Lohr ${ }^{2}$ \\ Department of Horticulture and Landscape Architecture, Washington State University, Pullman, WA 99164-6414
}

Human Issues in Horticulture $(\mathrm{HIH})$ is a relatively new aspect of horticulture research that focuses beyond traditional horticulture (the production, maintenance, and use of crops) to include understanding the humans who utilize the plants and the role that plants play in life quality. Quite simply, $\mathrm{HIH}$ is the study of the application of horticulture to all aspects of daily life.

The issues covered under the theme of HIH range widely. Based on the responses to calls for papers for symposia and workshops on $\mathrm{HIH}$, the self-selected topics include the widely recognized topics of economics and marketing; farming systems; fruit, vegetables, and herbs in relationship to health; environmental benefits and protection; and horticultural education. However topics also include less recognized areas such as healing landscapes, horticultural therapy, school gardening, community gardening, and other psycho-social issues. Presenters submitting papers come from a wide range of disciplines, partly because this research often depends on interdisciplinary collaboration for successful implementation, particularly where data is collected directly from humans.

It has only been in the last 25 years that significant research has accumulated on these aspects of horticulture and plant usage. In the 1970 s, researchers from forestry and environmental psychology initiated studies on the value of the urban forest to individuals and communities. Additional studies were conducted by researchers from a number of other disciplines, including economics, landscape architecture, and health care. They spurred the interests of horticulturists and laid the ground work for current and potential work. Over time, symposia such as Horticulture and Human Health, which looked at the health values of fruit and vegetables (Quebedeaux and Bliss, 1988) and The Role of Horticulture in Human Well-Being and Social Development (Relf, 1992b), which resulted in the formation of the People Plant Council (PPC), were being convened by horticulturists. The PPC now holds symposia every 2 years (Burchett et al., 1999; Flagler and Poincelot, 1994; Francis et al., 1994; Shoemaker, 2002; Williams and Zajicek, 1997). Horticulturists have convened HIH meetings world-wide. Symposia with published proceedings were held at International Horticulture Congresses (IHC) in August 1994 in Kyoto, Japan; in August 1998 in Brussels, Belgium; and in August 2002 in Toronto, Canada. The keynote colloquium and several other major presentations at IHC 2002 focused on HIH topics. In addition, three special issues of the ASHS publication, HortTechnology, have addressed HIH (Lohr, 2000; Relf, 1992a, 1995) (Fig. 1).

A recent paper on the status of HIH in the United States brought attention to some of the diverse and important facets of HIH currently being addressed (Lohr and Relf, 2000). In 2002 a national task force recognized the key role that horticulture and other aspects of urban agriculture play in the future of both our urban communities and agricultural profitability (Butler and Maronek, 2002). As public officials become increasingly aware of the importance of the human side of horticulture, the relevance of this arena is becoming increasingly clear to horticulturists as well as to those in other professions. Policy makers and professionals working in such areas as community and economic development, housing, policing, and public health are beginning to appreciate and promote benefits that plants can provide.

For the purpose of this paper, which will address both previous studies and current needs in this emerging field, HIH has been divided into seven areas: physical modifications to the environment; business and economic impacts; healthy communities and urban revitalization; individual health and health care facilities; fruit, vegetables, and herbs

${ }^{1}$ Professor emeritus.

${ }^{2}$ Professor. for health; education; and horticulture industry issues. It is anticipated that, as several of these areas already are covered by some ASHS working groups and there are an increasing number of professionals involved in research and applications, the entire area of HIH may someday be seen as the unnecessary grouping of extremely diverse topics under one title purely for moral support among a minor group of researchers. Or perhaps it will become part of a major restructuring of ASHS into such areas as crop production, biomechanisms, and HIH.

\section{PHYSICAL MODIFICATIONS TO THE ENVIRONMENT}

Physical environment modification, including improvements to urban air and water quality, heat reduction, and wildlife habitat creation, have been documented and are beginning to be quantified (Beckett et al., 2000; Michelfelder, 2003; Sailor, 1998). Plants help solve many of our urban environmental remediation and clean-up problems, including wastewater treatment, stormwater management, carbon sequestration, and indoor air quality, bringing vital and direct economic and life quality benefits. The interest of residents, industry, and governments in these applications promises to open doors to significant growth in the horticulture industry for the production of appropriate crops as well as the installation and maintenance of constructed natural sites.

Coder (1996) provides an extensive list of research-based information on the environmental impact of plants on the urban environment from the last 25 years, with particular emphasis on cost analysis including: reduced heating and cooling costs, runoff and erosion control, filtering of noise, glare reduction, filtering of airborne particulates, and $\mathrm{CO}_{2}$ reduction. Recently horticulturists have increased their interest in research regarding the values and impacts of physical modification of the environment using plants with, for example, the work on green roof systems at Michigan State University (Monterusso et al., 2002).

Since the Kyoto Protocol and the development of tradable emission permits and tradable carbon offsets, the role of planted forests (including parklands and street tree plantings in urban areas) for carbon sequestration to reduce atmospheric carbon has real monetary significance (DiNicola et al., 1997). In addition, trees in urban areas

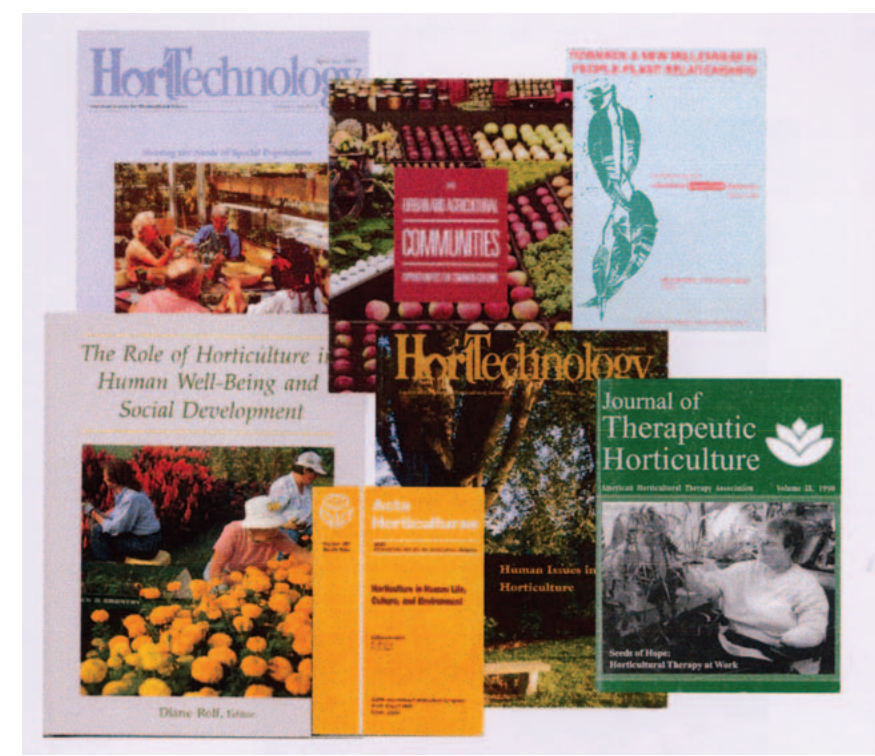

Fig 1. Books, proceedings, and journals now publish articles related to human issues in horticulture. 


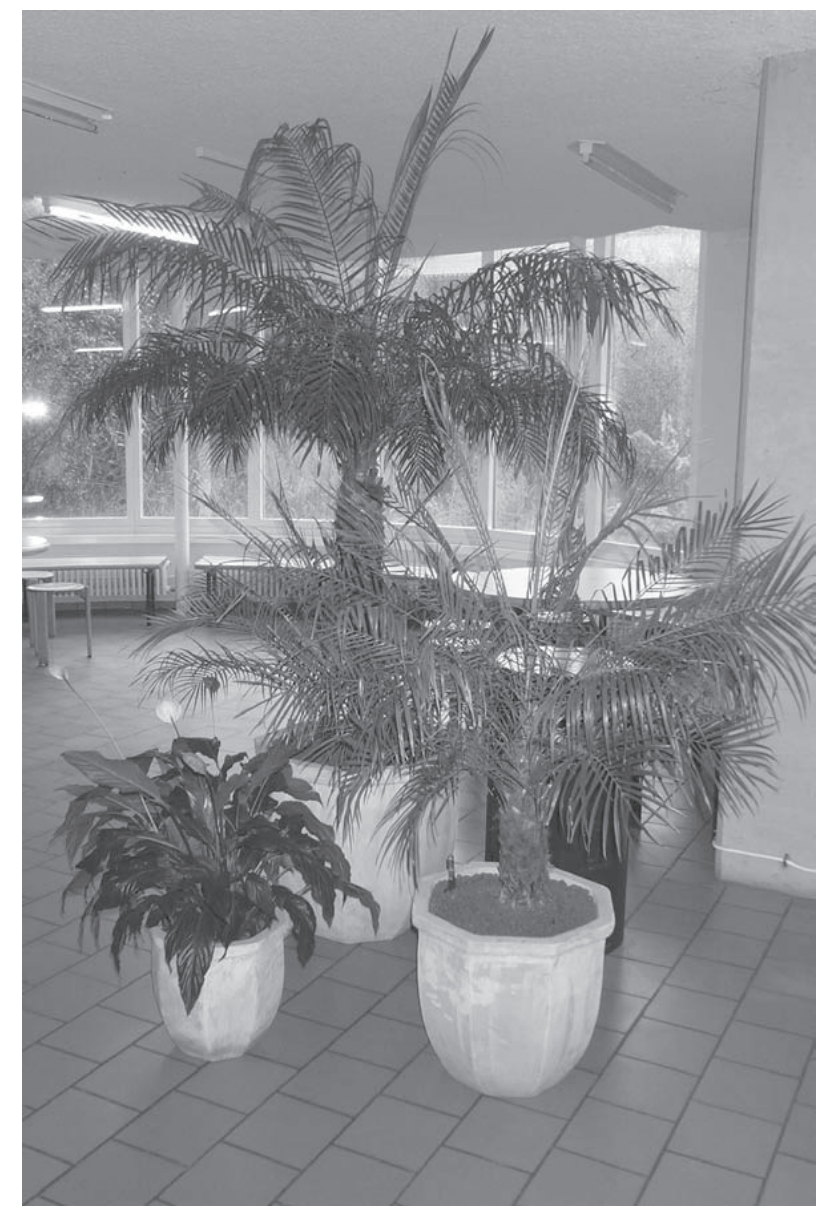

Fig. 2. Significant research has been done to understand the role of interior plants in phytoremediation.

influence atmospheric carbon emissions indirectly by affecting heating and cooling loads in buildings, which can contribute greatly to carbon reductions under many conditions (Jo and McPherson, 2001). Landscape horticulturists who understand these relationships will be able to make significant contributions through the appropriate selection and placement of trees in urban areas.

Interior plants play a role in phytoremediation, and significant work has been done in this area (Fig. 2). Early studies funded by the National Aeronautics and Space Administration on indoor air quality indicated that plants may help reduce sick-building syndrome, for example, by removing formaldehyde and other pollutants (Wolverton et al., 1984; 1989). Rhizosphere microorganisms, which were revealed to provide the mechanism of removal, depend on the presence of healthy plant roots (Wolverton et al., 1989; Wood et al., 2002). The research has been extended to show that plants remove many indoor air pollutants including toluene and benzene (Darlington et al., 2001; Wood et al., 2002). Other research has revealed that plants do not contribute excessive humidity to interiors, which could damage building materials, as many building specialists had feared, but can raise the relative humidity from levels below the range recommended for human health to levels within the range (Lohr 1992a, 1992b). The presence of interior plants and their dusty potting media do not make air dustier; in fact, adding plants to the periphery of a room can reduce particulate matter deposition by as much as 20\% (Lohr and Pearson-Mims, 1996). Airborne microorganisms also appear not to be a problem. In one study, the quantity of interior mold spores and airborne microorganisms was actually lower when interior plants were present (Wolverton and Wolverton, 1993). Based on findings such as these, Darlington et al. (2001) developed a biofiltration unit with interior plants and an aquarium that can effectively maintain healthy indoor air even in interior spaces with extremely low rates of air exchange. This research has created a great opportunity for the interiorscape industry to market its service of installing and maintaining healthy plants (ALCA, 2001; Plants for People, 2002) (Fig. 3).

\section{BUSINESS AND ECONOMIC IMPACTS}

Economic development issues that have received attention from researchers include the impact of plants on the profitability of businesses, increased real-estate values, the role plants play in tourism and recreational sites, and the economic impact of ornamental horticulture businesses such as nurseries and landscape maintenance firms. The atmosphere of a community can have significant economic impact as it influences how community members perceive themselves, value their surroundings, and spend money. It also influences decisions from others on supporting or becoming involved in the community.

Researchers have evaluated the economic value of plants in community settings. Wolfe (1998a, 1998b) identified benefits versus costs associated with business development through the use of trees: increasing return visits, presenting a message of care, and creating a perception of higher quality merchandise versus reduced usable parking space and increased waste from tree debris. She found consumers' perceptions of business districts and willingness to pay for similar merchandise were significantly higher for those that had street trees and other landscape improvements. Goldsteen (1989) found that landscaping was more highly correlated with high occupancy rates than architectural features, access to freeways, or even rental rates in high-rise office complexes during a time of overbuilding when occupancy rates were generally low, yet rates remained high in some buildings. In another study, Browne (1992) showed that plants also impact residential occupancy and influence where people choose to live: among residents of retirement communities, pleasant, landscaped grounds were important or essential to $99 \%$ of the residents and were given as the most important reason for selecting a particular retirement community. While it is widely recognized in the real estate industry that homes with better landscapes will sell for higher prices, few people in the real estate industry have considered methods to include this value in appraisals (Dombrow et al., 2000). Some quantitative data on which to base prices is now available. Henry (1994), for example, compared the actual sale prices of similar homes and reported that the sales price of a home with excellent landscaping (as rated by a landscape professional) was $12 \%$ to $15 \%$ higher than one with fair or poor landscaping.

Businesses also benefit financially when the presence of plants positively affects employees. As early as 1988, Kaplan et al. (1988) reported that workers with a view of natural elements, such as trees and flowers, experienced less job pressure, were more satisfied with their jobs, and reported fewer ailments and headaches than those who either had no outside view or could only see built elements from their windows. More recently Lohr et al. (1996) documented increased productivity on a computer task performed in a room with interior foliage plants compared to one without plants. Fjeld (2000) found that workers in an office with foliage plants reported fewer physical symptoms including coughing, hoarse throat, and fatigue than when no plants were present, translating into more productive workers.

The recreation and leisure industries are significantly impacted by horticulture, as was revealed in a National Gardening Association survey conducted by the Gallup Organization (Relf et al., 1992). Half of the respondents indicated that plants and flowers at theme parks, historic sites, golf courses, and restaurants were important to the enjoyment of visiting there. A study conducted by Evans and Malone (1992) at Opryland to determine the value of interior plants to the hotel/tourism industry attributed several positive impacts to their greatscapes, most significantly, the higher occupancy and room rates overlooking the gardens translated into $\$ 7$ million in additional room revenue annually. Botanical gardens, zoos, sculpture gardens, and the gardens at historical sites and museums are estimated to attract more than 35 million visitors each year. Botanic garden visits reduce perceptions of stress and improve feelings of well-being (Bennett and Swasey, 1996; Hamilton and DeMarrais, 2001; Kohlleppel et al., 2002). One study, using the travel cost method, estimated that users obtained \$20.43 in value from a visit to an arboretum (Downing and Roberts, 1991). In addition, flower, vegetable, and tree festivals increasingly draw tourists and entertain local residents. Demand for recreational activities dependent upon the products and services of environmental horticulture (e.g., athletic fields, parks, golf courses) will continue to increase as population increases (Templeton et al., 2000). 
In addition to the impact that the plants have on the economic health of businesses in a community, the environmental horticulture and floral industries have direct and significant impacts in terms of landscaping, maintenance, and wholesale/retail sales. The annual National Gardening Association Survey has for a number of years reported that about $70 \%$ of U.S. households participated in some form of lawn and garden activity involving the purchase of horticultural products or services. ANLA (2002) reports increase expenditures of about $\$ 3$ billion a year for the last 5 years for landscape and trees installation and maintenance from $\$ 16.8$ to $\$ 28.9$ billion (Fig. 3). In addition to the traditional business impacts such as providing jobs and paying local taxes, economic multiplier effects from these businesses are beginning to be reported by $\mathrm{HIH}$ researchers that are little understood or explored including employment for entry level, disabled, youth-at-risk, and other individuals which may also have the added value of producing taxpaying citizens, reducing crime and other social costs. (Bradley, 1999; DeHart-Bennett and Relf, 1990a; Eastman, 1999; Flagler, 1995; McGuinn and Relf, 2001).

\section{HEALTHY COMMUNITIES AND URBAN REVITALIZATION}

Plants and gardening enhance communities in many ways beyond business and economic impacts; ranging from a greater sense of community to reduced crime, benefits that have tremendous economic and social implications for creating healthy communities and revitalizing urban districts. There is strong indication that urban greening is highly successful in building communities and reducing the public health hazards associated with isolation, loneliness, and lack of community ties. Formal research on the psychological and social impacts of plants and the natural environment on people began to appear in the 1970s (Kaplan, 1973; Talbott et al., 1976). Initially researchers studied the role of nature/vegetation/plants in terms of preferences, perceptions, and neighborhood satisfaction. Several strong indicators of the importance of plants were reported in the early 1980s. For example, a study in Atlanta (Brogan and Douglas, 1980) indicated that the characteristics of physical environments (e.g., landscaping and nearby land use) were equally important to sociocultural factors (e.g., population density and income) in explaining the variations in the psychosocial health of the community. Fried (1982) reported that the strongest indicator of local residential satisfaction was the ease of access to nature, and Getz et al. (1982) reported that parks and street trees were second only to education in the perceived value of municipal services offered.

Community gardens likewise play an important role in healthy communities. Blair et al. (1991) found that gardeners more than control group members tended to regard their neighbors as friendly. Feenstra et al.(1999) reported positive social impacts, including the promotion of neighborhood cohesion and trust and reducing racial discrimination. USDA Cooperative Extension gardening programs reported socioeconomic (Patel, 1992) and community development value (Grieshop, 1984).

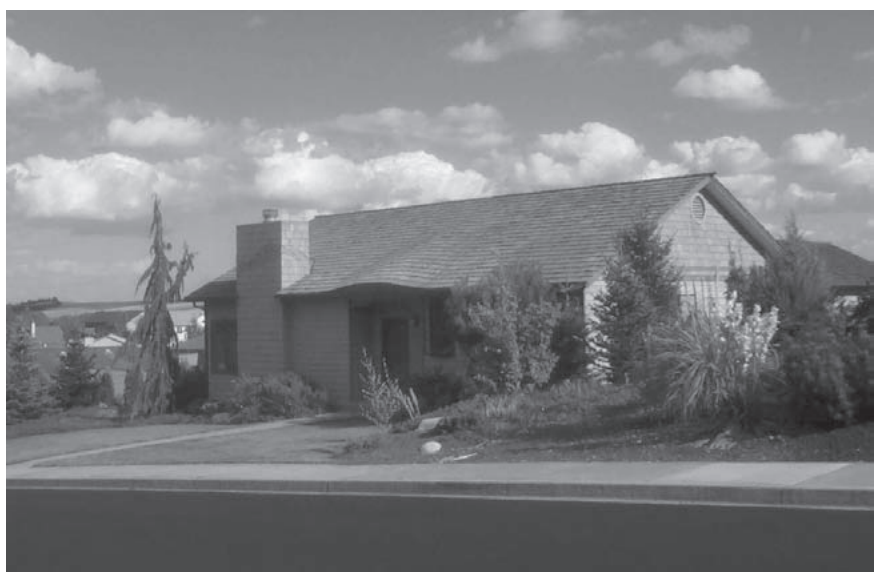

Fig. 3. As use of plants increases, expenditures for landscape and tree installation and maintenance have increased by about $\$ 3$ billion per year for the last 5 years according to ANLA.
Recent research has increased our understanding of some the specific social impacts of plants in communities. Kuo and Sullivan, directors of the Human-Environment Research Laboratory at the University of Illinois, found that in public housing neighborhoods where residents are randomly assigned to particular buildings, green landscapes led to better social functioning, better interpersonal relations, less verbal aggression, less physical aggression, and less violence (Kuo et al., 1998). Spending time in green outdoor spaces has also been systematically related to stronger social integration and stronger sense of community for older adults (Kweon et al., 1998). In other studies, green landscapes led to better parental functioning - more parental supervision and discipline, less parental aggression and violence (Taylor et al., 1998). Green landscapes also fostered activities that support healthy development in children (Coley et al., 1997; Taylor et al., 1998).

Social scientists are documenting the impact of green environments on community safety. Green outdoor spaces have been linked to a lower incidence of violence (Kuo and Sullivan, 1996) as well as reduced vandalism, litter, graffiti and a lower incidence of crime, as measured by police reports (Kuo and Sullivan, 2001). In one Philadelphia neighborhood, residents' involvement in community greening was the catalyst for a 90\% reduction in neighborhood crime (Macpherson, 1993) (Fig. 4). The links from community gardens to lower rates of various crimes have been widely documented (Feenstra et al., 1999; Littman, 1996; Malakoff, 1995). Lockwood and Stillings (2001) reported that one of the significant effects of traffic calming/streetscaping efforts has been a reduction in crimes related to poor street environments. For example, within the Old Northwood and Northboro neighborhoods of West Palm Beach arrests for prostitution dropped $80 \%$ and drugs $60 \%$ as the streets became safer and more useable.

The impact of the environment and its design on community health is receiving attention from various sources for a wide range of effects from speeding and road-rage to obesity. This promises to be an area that demands collaboration from horticultural researchers. Streetscaping techniques are among factors that help manage traffic effectively by reducing car speeds and collision frequency (Lockwood and Stillings, 2001). Roadside character affects drivers' stress response based on physiological indicators, such as heart rate and skin conductance (Parsons et al., 1998). Viewing strip-mall style roadside environments impeded recovery from stressful situations, while roadside nature scenes (forests or golf courses) enhanced the return to normal and the ability to cope with introduced stressors. The Centers for Disease Control and Prevention attribute obesity and other major community health issues to a sedentary lifestyle due, in part, to lack of appropriate walking and

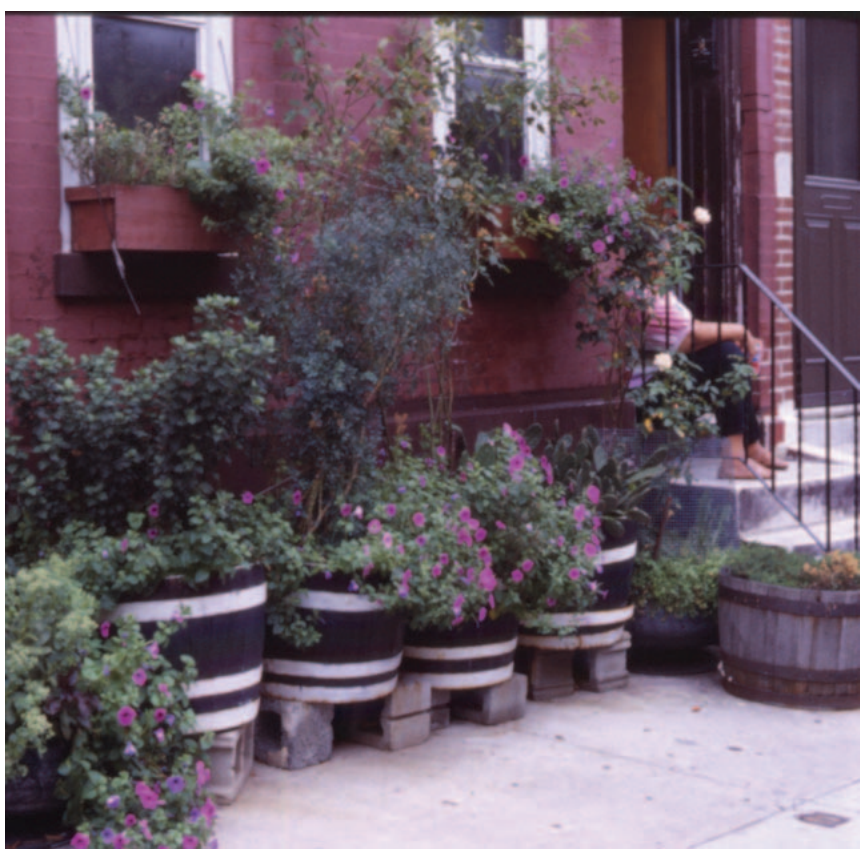

Fig. 4. Community greening, such as shown in Philadelphia, has been documented to lower rates of various crimes. 


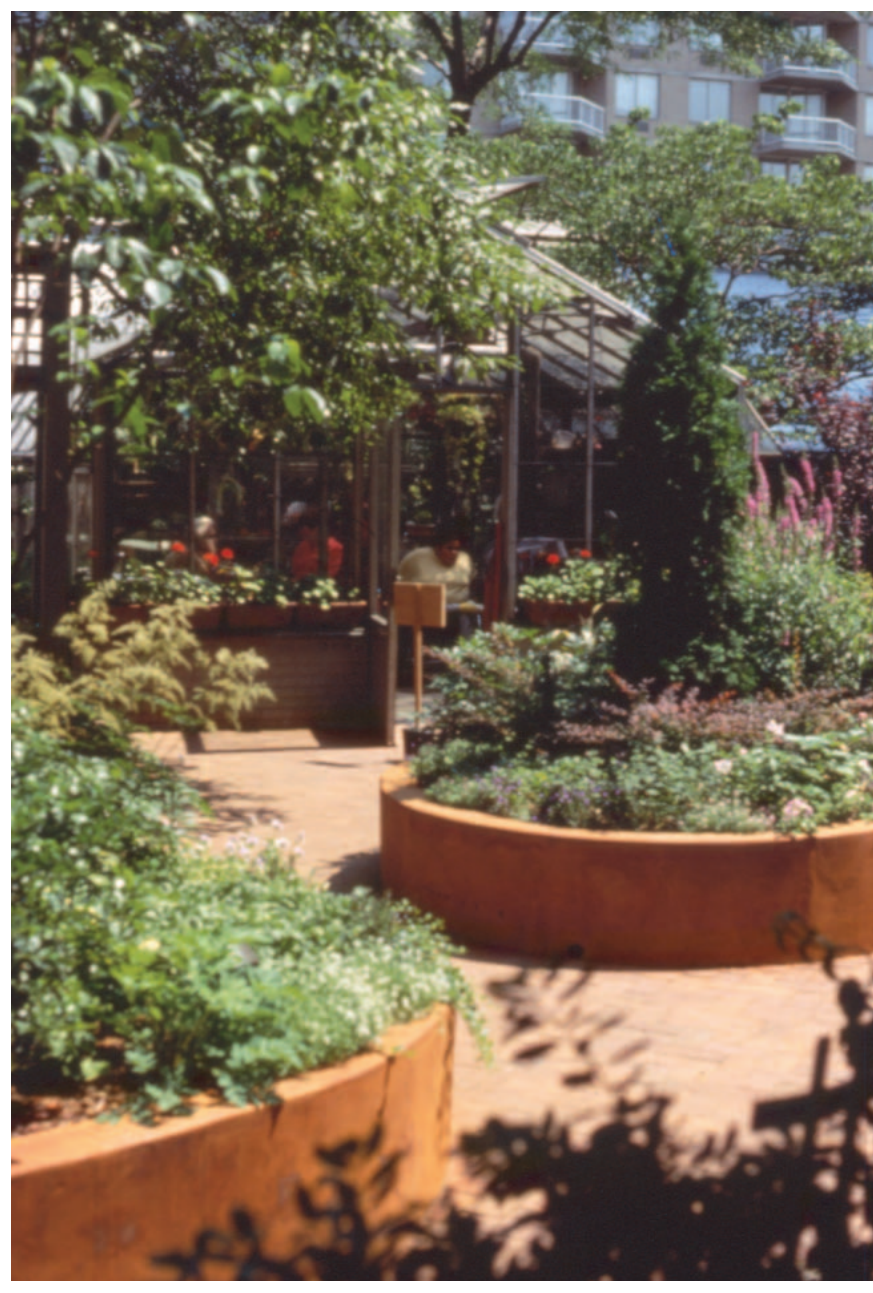

Fig. 5. The perennial garden at the Rusk Institute of Rehabilitation Medicine, a part of the Enid A. Haupt Glass Garden, is well used throughout the year by staff, visitors, and patients at the institute and serves as a classroom for horticultural therapy groups.

biking areas as part of people's normal, everyday lifestyle.

Frumkin (2001) at Emory University School of Public Health has called for more collaborative, clinical, and epidemiological research documenting the benefits of interactions with natural landscape, plants, and animals, so that prescriptive interventions for specific illnesses could be offered by the medical community and supported by health insurance companies. He points out that such research would also foster zoning and planning decisions that would promote greater community health. This has significant implications for the landscape design, installation, and maintenance components of the environmental horticulture industry and holds the potential for increasing production and marketing demands, as horticulturists accept the challenge of working with community health professionals.

\section{INDIVIDUAL HEALTH AND HEALTH CARE FACILITIES}

The health effects of plants have been promoted for centuries, and research has now documented that the benefits are not just a placebo effect. Documented health benefits, which range from stress reduction to improved outcomes for specific ailments, accrue from working with plants, merely being in the presence of plants and viewing them, and consuming healthful fruit, vegetables, and herbs (see: Fruit, vegetables, and herbs for health). Healing landscapes and horticultural therapy have become increasingly viable and researched fields of study.

Various studies have related plants and gardening to improved wellbeing and reduced stress. Physiological changes related to recovery from stress include lower blood pressure and reduced muscle tension when viewing scenes of nature compared to urban scenes (Ulrich and Simons, 1986) or plant-based décor (Wise and Rosenberg, 1988). Testing subjects in a room with or without potted plants present, Lohr et al. (1996) found participants were less stressed and reported feeling more attentive in the room with plants. Tennessen and Cimprich (1995) reported that college students in dormitory rooms with a view of nature performed significantly better on some tasks that required mental concentration than did students with a view that was dominated by hardscape. Beneficial effects of the presences of plants on the perception of pain have also been recorded (Lohr and Pearson-Mims, 2000).

Work also is being done to evaluate the impact of active participation in gardening on general well-being. In a national survey, Relf et al. (1992) found $24 \%$ of respondents said gardening gave them a sense of control over their immediate environment, $40 \%$ reported that plants helped them feel calmer and more relaxed, and $46 \%$ felt that nature was essential to their well-being. Other benefits such as increased selfesteem, enhanced personal satisfaction and efficacy, and greater sense of stability among gardeners have also been found (Blair et al., 1991; Feenstra et al., 1999; Pothukuchi and Bickes, 2001). Studies have also found that gardeners report increased satisfaction with the quality of their lives (Waliczek et al., 1996) and that gardens contribute to community spirit (Littman, 1996). Taylor (1990) cites several sources to illustrate the exercise value of gardening; for example, you can burn as many calories in $45 \mathrm{~min}$ of gardening as in $30 \mathrm{~min}$ of aerobics. Based on research and experience, Mattson (1992) advocated prescribing health benefits through horticultural activities.

Other studies have examined subjects with specific health problems. A classic study showed that patients recovering from gall bladder surgery spent less time in the hospital and used fewer doses of strong pain relievers if they had a room with a view of trees rather than a view of a brick wall (Ulrich, 1984). Another study showed that restorative activities such as walking in a garden help women recover from breast cancer (Cimprich, 1993). Patients with Alzheimer's disease in facilities with landscaped areas for walking exhibited fewer violent outbursts than did patients in facilities with only hardscapes (Mooney and Nicell, 1992). Symptoms in children with attention deficit disorder (ADD) have also been shown to be reduced when they spend time in settings with increasing amounts of nature and plants present (Taylor et al., 2001). Another study used a measure of ADD behaviors to document an improvement in children's ability to concentrate when they moved from low income housing with few or no green spaces to homes with increased green (Wells, 2000). Women over 50 years of age were examined in a study of osteoporosis (Turner et al., 2002). High bone mineral density, which is related to a lowered risk of osteoporosis, has been associated with weight-bearing activities. In this study, bone density was as high in women who did yard work as in those who did weight training, and it was higher than in women who did jogging, aerobics, or calisthenics. In a review article, Relf and Dorn (1995) provided information on research and resources to enhance the application of horticulture to meet the needs of various groups of individuals.

As a result of the earlier studies of Ulrich (1984) and the Kaplans (1989), the concept of designing landscapes at hospitals, hospices, and similar sites for their healing qualities rather than merely to cover the grounds is gaining favor. Landscape architects actively explore healing and therapeutic landscapes and gardens designed for horticultural therapy. The uniqueness of landscape design for nursing homes and other housing facilities for elderly and disabled persons is becoming internationally recognized (Gerlach-Spriggs et al., 1998). Research sponsored by the Center for Health Design on the use and therapeutic benefits of hospital gardens finds an overwhelmingly positive response from employees, patients, and their families and friends (Marcus and Barnes, 1999) (Fig. 5).

Horticulture as therapy for individuals with a variety of diagnoses has a long history [Hefley (Relf), 1973a; Hefley (Relf) and Sperling, 1973b; Watson and Burlingame, 1960]. It has been used effectively in psychiatric hospitals since the late 1800s (Friends, 2003; Hewson, 1994; McCandliss, 1967). It likewise has a long history of use with individuals with intellectual impairments (DeHart-Bennett and Relf, 1990b; Dobbs and Relf, 1991; Lawrence, 1900; Relf et al., 1982) particularly in vocational and educational centers (Doxon et al., 1987, Relf, 1981a). Programs are also found in rehabilitation hospitals (Ka- 
vanagh and Chambers, 1995; Rusk, 2003) and Veterans Administration hospitals (Virginia Medical Center, 2003). In addition, arboreta and botanic gardens (Chicago, 2003; Holden, 2003) are employing registered horticultural therapists to conduct educational outreach programs for professionals and clients in treatment facilities in their communities. Historically volunteers have started many programs in hospitals and nursing homes that went on to become part of the professional adjunctive therapies (Burlingame, 1974; Watson and Burlingame, 1960). One of the most important new contributors to volunteering in HT is the Cooperative Extension Master Gardeners (Flagler, 1992), a role which will be enhanced by more knowledge of motivation and methods.

With such diverse populations served, goals of the programs differ, but the basic premise behind horticultural therapy is that working with living plants brings about positive psychological, social, intellectual, and physical changes that improve the quality of life for the individual (Hefley (Relf), 1973a) Theories have been put forth (Relf, 1981b; Shoemaker and Mattson, 1982), but a significant amount of research is needed to establish a shared body of knowledge that would enhance the growth and impact of this professional area. The American Horticultural Therapy Association (2003) was established in 1973 and has published an annual refereed journal since 1986, thus increasing the number of both research and program articles available to its members.

The aging population makes understanding the impact, value, and techniques of gardening for older individuals equally important for individuals in the community as for those in a treatment setting. One study showed that older people living in housing units with common outdoor spaces planted with trees experienced more positive interactions with their neighbors than did those living in units with common outdoor spaces with paving (Kweon et al., 1998). Early studies focused on this population (Mattson and Hilbert, 1976). The therapeutic benefits of horticultural activities for older individuals are attributed to several factors including anticipation of the future as the gardener waits for the flower or ripening fruit (Relf, 1978); the sense of pride and accomplishment associated with horticultural success (Hill and Relf, 1982; Matsuo, 1995); and the sensory stimulation of the tactile, aural, olfactory or visual senses by plants, which can trigger individuals' memories and stimulate reminiscence (Namazi and Haynes, 1994).

Two separate studies (Kerrigan and Stevenson, 1997; Predny and Relf, 2000) of intergenerational programming using horticultural therapy in daycare facilities for adults found that horticultural activities that focused on plant culture resulted in greater interaction than those activities that involved craft-type work. Studies of seniors in intermediate care (Mooney, 1994) and elderly adults with cognitive impairment, such as Alzheimer's disease (Mooney and Nicell, 1992) have reported positive results from properly designed outdoor environments. Further, Jarrott et al. (2002) reports positive responses to horticulture activities from seniors with Alzheimer's disease in an adult day services program.

\section{FRUIT, VEGETABLES, AND HERBS FOR HEALTH}

Exploration to enhance the health giving attributes of fruit and vegetables and the medicinal aspects of herbs have become major areas for collaborative research by horticulturists and scientists from a number of fields. Raskin et al. (2002) provide a review of the history, future, scientific background, and regulatory issues related to botanical therapeutics. They discuss the impact that a change in premise from growing crops for health rather than for food or fiber is having on changing plant biotechnology and medicine. According to these authors, the rediscovery of the connection between plants and health is responsible for many of the pursuits of plant biotechnology today. The current research focuses on a new generation of botanical therapeutics including: plant-derived pharmaceuticals, multi-component botanical drugs, dietary supplements, functional foods, and plant-produced recombinant proteins. Not only will the products resulting from this new context of study result in products to complement conventional pharmaceuticals in the treatment, prevention, and diagnosis of diseases, it will add value to agriculture commodities. Likewise, a recent issue of HortTechnology providing proceedings of the workshop on the History of Horticulture and Human Health explored this aspect of the relationship between horticulture and fruit, vegetables, and herbs (Craker and Gardner, 2003a, 2003b; Janick, 2003; Palaniswamy, 2003; Read, 2003).
Community gardens are associated with increased food security and food quality (Butler and Maronek, 2002). In developing countries, a major need has long been identified, but still neglected by horticulturists, to understand the social and cultural aspects as well as technical and biological aspects of local food production and consumption from a farming systems approach, in order to strengthen the potential impact of food production efforts. In addition, home food production may have important economic and nutritional impact. Surveys conducted by the Gallop Organization for the National Gardening Association (Butterfield, 2000), indicated that $29 \%$ of all U.S. households or 31 million households participated in vegetable gardening and $13 \%$ or 13 million households cared for fruit trees. A study of selected Philadelphia gardens found that almost half had yields valued at between $\$ 101$ and $\$ 250$, with $15 \%$ yielding between $\$ 251$ and $\$ 500$ (Blair et al., 1991) reducing the costs to the consumer and significantly increasing the potential for the gardener to eat fresh vegetables. Pothukuchi and Bickes (2001) found that after participation in a youth garden in Detroit, children were able to name and knew more about the nutritional value of particular vegetables. Parents also reported that kids were asking for and consuming more vegetables in their meals. Cavaliere (1987) found that vegetables grown by students had a high intrinsic value. Lineberger (1999) found that school gardening and nutrition-curriculum improved students' attitudes toward fruit and vegetable snacks.

\section{EDUCATION}

Education issues encompass a diversity of topics related to horticulture including the use of the garden as a tool for environmental awareness and across-the-curriculum teaching in K-6 schools, vocational horticulture, Cooperative Extension Master Gardener (MG) training, optimum techniques for university level horticulture courses, and teaching about HIH. On the one hand, the changes in learning styles and opportunities resulting from computer technology are forcing teachers of traditionally hands-on courses to understand how their students learn and adapt teaching accordingly. On the other hand, research is beginning to indicate that gardens in public schools can serve as effective tools for motivating student learning in many subjects because it is a hands-on experience.

Historically gardening has been an integral part of a child's life and played a significant role in how and what they learned. However, in recent years youth are increasingly isolated from the natural world and opportunities to nurture life around them. Because of current educational pressures and the overwhelming number of recreation opportunities, it becomes increasingly important to understand the benefits and the needs that children have for both plants in their immediate surroundings and the opportunity to work with and be responsible for them.

In an early study, children who participated in horticultural activities (Bunn, 1986) demonstrated more group cohesiveness than those who did not. Researchers (Campbell et al., 1997; Skelly and Zajicek, 1998; Waliczek and Zajicek, 1999) reported that participation in Texas A\&M University's Project GREEN (Gardening Resources for Environmental Education Now) resulted in significantly improved environmental attitudes among children, while adolescents also improved interpersonal relationships as a result of participation. Lohr and Pearson-Mims (2002) showed that similar improved attitudes appear to be carried into adulthood. Adults who held positive attitudes towards trees were more likely to have had nature or environmental education in elementary school than adults who did not participate in such programs.

Participants completing the Green Brigade program for juvenile offenders significantly improved their horticultural knowledge and environmental attitude scores. The program was found to be as effective as traditional probationary programming at reducing the crime rates of juvenile offenders (Dawson and Zajicek, 1999). Flagler (1993) reported success from a specialized youth correctional training program which allowed youth to gain knowledge, responsibility, and achievement through hands-on experience. McGuinn and Relf (2001) suggest that vocational horticulture curricula may be a tool to strengthen a delinquent individual's bonds with society and, subsequently, evoke changes in attitudes about personal success and perceptions of personal job preparedness.

Dobbs et al. (1998) found that $88 \%$ of the teachers surveyed from 


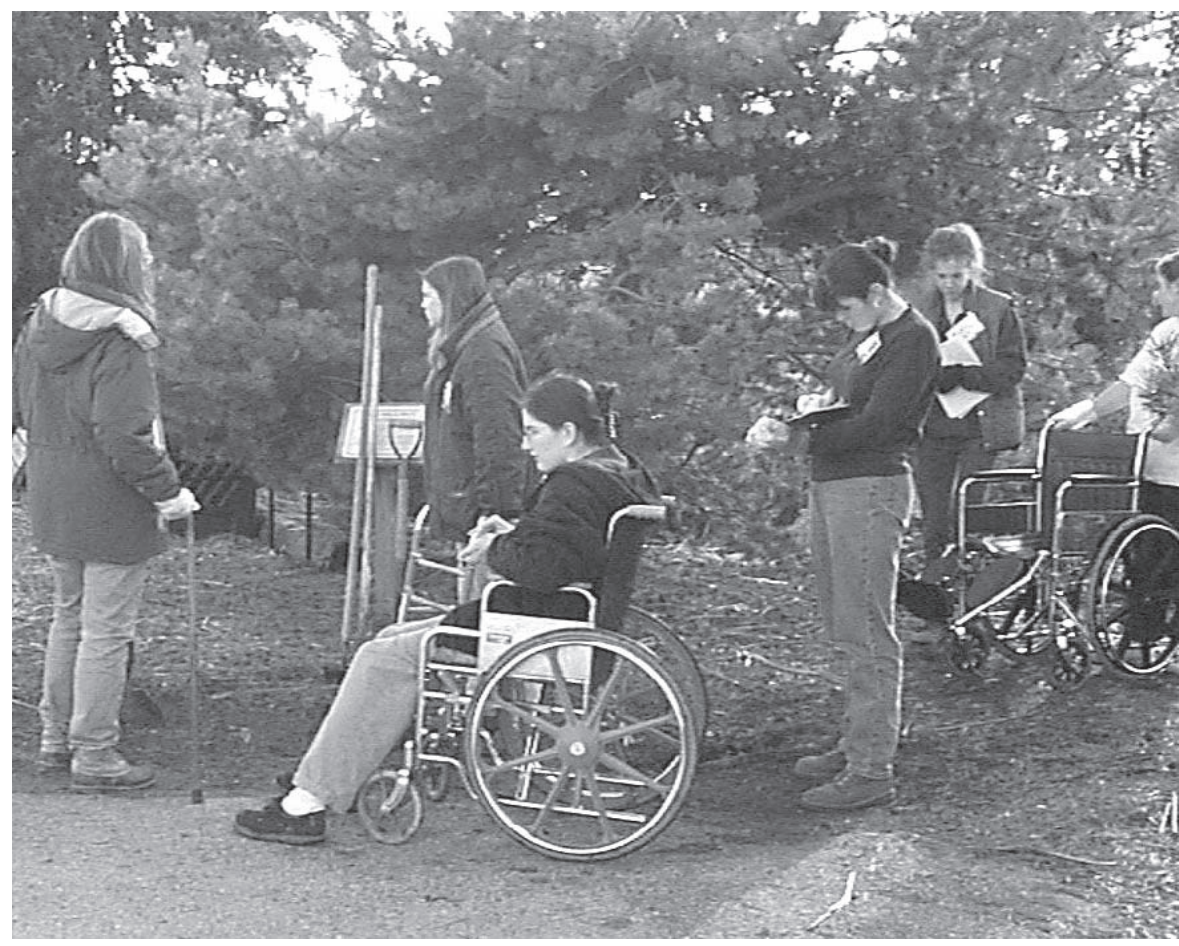

management of MGs. Studies have shown that nearly all MGs come to the program because of their desire to learn more about horticulture and gardening (Schrock et al., 2000; Meyer, 1997). They stay with this program because they continue to have new learning experiences and opportunities to help other people. These opportunities allow MGs to increase their selfesteem and self-enhancement, provide social benefits, and develop potential career-building skills (Schrock et al., 2000). Volunteer projects allow MGs to make connections that provide themselves and participants with a sense of purpose (Meyer, 1997). Dorn and Relf (2001) report that management structure and tools which reduce the questions and confusion over conducting a program are valuable to Virginia Cooperative Extension MGs.

Referred publications on university level horticulture courses are not new. Various reports have appeared over the years (ASHS, 1970; Ballinger, 1980; Steavenson et al., 1975). Many of these have been descriptive, allowing instructors to share what has been effective in their programs (Berghage and Lownds, 1991; Carpenter, 1972). Research comparing the effectiveness of specific courses has also appeared (Anderson and Walker, 2003; Lohr

Fig. 6. Horticultural therapy students use wheelchairs and other tools to assess the accessibility of the Virginia Tech Horticultural Garden

elementary schools across the state expressed interest in introducing gardening to the classroom to meet the Virginia Standards of Learning across the curriculum. The greatest needs expressed by these teachers were for teaching resources (e.g., lesson plans and teaching aids), volunteer support (e.g., MGs), and teacher training. DeMarco et al. (1999) surveyed teachers nationally who had received National Gardening Association garden grants. The most important factor in the successful integration of gardening into the school curriculum was the perception of ownership of the concepts and goals by the teachers and students. Teachers reported gardens were successful as a teaching tool. These studies have resulted in a graduate-level summer intensive course for teachers which is taught in cooperation with urban botanical gardens, additional training for MGs, and on-line projects called the Young Virginia Gardener.

Education of the public or amateur gardener tends to be diverse and unstructured with opportunities taking many forms including the Internet, magazines, and courses at nurseries and botanic gardens. There is little documentation on this form of horticultural education, yet it offers significant potential for expanding the use of horticultural products and services as well as providing jobs for university horticulture graduates. Cooperative Extension has been providing both problem solving and educational programming to the public since its inception. To meet the demand for gardening information from the predominately suburban clientele, the MG volunteer training program was developed in 1972 in Washington state and spread nationally (Bobbitt, 1997). In addition to traditional garden presentations and similar educations programs, MGs are involved in areas such as horticultural therapy, (Flagler, 1992; Meyer, 1997), information distribution through Horticulture Hotlines (Ruppert et al., 1997) and Plant Clinics (Amundsen et al., 1997). MGs help in school and youth gardens, working with parents, teachers, and extension agents to deliver structured horticulture activities in the classroom or through horticulture clubs (Meyer, 1997). Other MGs work with inner-city youth to develop organic market gardens (Meyer, 1997) and at-risk youth with learn-and-earn restitution programs (Finch, 1997) to give life skills and career training. They are becoming a key element in long-term impact-based education programs such as the Water Wise Gardener (Dorn et al., 1996).

Recognition that a better understanding of MG programs will facilitate cooperative extension efforts in this area has resulted in an increase in refereed publications regarding educational programs, motivation, and and Cotter, 1984). As new teaching techniques and technologies become available, such as teaching over the Internet, horticulturists have also shared ideas about incorporating these into the curriculum (Anderson and Walker, 2003; Holford et al., 2001; White et al., 1990).

Teaching specifically related to HIH has taken two forms. The first relates to specific courses to teach students applications and techniques. These exist at a number of universities, including Kansas State University, Rutgers University, and Virginia Polytechnic Institute and State University (Fig. 6). The second form relates to teaching horticulturists about conducting research in $\mathrm{HIH}$. Because this research usually involves the study of people, horticulturists need additional training in the methods of the social sciences. This has been addressed through ASHS Workshops such as Social Science Research Methods in 1991 and Exploring Research Methodologies in HIH in 1998. Much of this was summarized in a recent article by Shoemaker et al. (2000).

\section{HORTICULTURE INDUSTRY ISSUES}

Horticulture industry issues of greatest importance today are frequently centered on human factors such as employee training, retention, and workplace health. Areas that have received more work from horticultural researchers include marketing issues such as consumer preference. Such studies as analysis of consumer purchases of floral products in supermarkets (Behe et al., 1992) have contributed to an understanding of impacts of market shifts, helping the industry better place itself competitively. Behe and Barton (2000) have made important contributions by expanding studies of consumer perceptions of product and service quality to encompass multiple states. Studies that address relationships among and characteristics of horticultural business have been important and indicate the need for significantly more information in this area. Garber and Bondari (1992, 1995, 1996, 1998) published several series of studies covering landscape architects as related to the landscape/nursery industry, landscape installation firms, landscape maintenance firms, retail garden outlets and exploring business aspects from pest management practices to trends affecting industry performance.

An industry issue directly impacted by knowledge and understanding of the consumer is expansion into new marketing areas of value-added food crops such as organically grown fruit and vegetables, genetically engineered (GE) crops for enhanced health or production benefits, and GE-free crops. Farmers market, pick-your-own, and communitysupported agriculture (CSA) are alternative marketing schemes being explored by agricultural economists and horticulturists. They offer 
alternative production and/or marketing systems where consumers not only purchase food, they gain the opportunity for experiences and social interchange not found in our modern food chain. CSAs are often integrated into social programs such as mental health or low-income housing.

Organic products must be certified under organic rules adopted by the USDA in 1997 Agricultural Marketing Service, 2003). The label organic permits both producer and consumer to express a product preference based on a personal philosophy, thus adding value such that something more than the food product itself changes hands. Increased knowledge of the motivations of buyers and the value added aspects of these enterprises combined with an understanding of its impact on production techniques will significantly increase the profitability to the business.

On-site recreation or tourism opportunities are increasingly being provided to the public in various forms, such as painting/music in the garden, events (i.e., maple sugaring), dinner in the herb garden, and specifically built tourist attractions, such as the amazing maize maze. Tyrväinen (2001) found that people want green nature based recreation areas in their cities and $82 \%$ of users were willing to pay for the recreational experiences these sites provide. A cost-benefit analysis revealed that revenues could be as much as 25 times more than the costs. In addition to the experience, value-added products can increase profits. The visitor may buy gift packs of fruit or homemade jam, select a pumpkin for Halloween, or purchase a related decorative item. Linked education events to enhance the operation include school tours, seminars, classes, and other offerings where the group is expected to gain knowledge and skills. Green industry production units often have visual appeal that offers a tourism function. The Flower Fields in California (Lobo et al., 1999) is a working farm where ranunculus and other flowers grown for the commercial production of bulbs and cut flowers rival the tulip fields of Holland in beauty. An economic study of this operation revealed that the over 200,000 people who visit during the 10 weeks of spring bloom produced an additional $\$ 600,000$ in annual revenue from paid admissions to the fields and a total economic impact of $\$ 3.8$ million in tourism annually for the local community. Ellison's Greenhouses in Texas (Bruhn, 1999) charges for guided tours of one of their 100,000 square foot production greenhouses 6 days a week. During their annual poinsettia celebration, 5,000 persons visit. Ellison's also surveys these consumers to gather useful marketing information.

\section{CONCLUSIONS}

The fact that people need plants for their very survival is understood by virtually everyone. Without plants to harvest sunlight and provide food, we could not live. We use the products of plants to build homes, provide medicines, and clothe ourselves. Human culture and evolution have been directly impacted by the beauty of plants in our environment and in our gardens since the earliest known humans. These are obvious needs fulfilled by plants. What is also now evident from recent research is that plants do much more. They clean our environment, improve our physical health, boost our businesses, make our communities safer, contribute positively to our mental health, ..., this list goes on and on.

As with all other aspects of horticulture, $\mathrm{HIH}$ should be incorporated into our research, teaching, and outreach efforts. While a solid research base now documents the existence of a vast array of human interactions with plants, much more research is needed to take full advantage of the myriad benefits that can be provided by plants. For example, we know that domestic violence is lower among residents in apartments with vegetation than among residents in apartments without vegetation (Kuo and Sullivan, 1996). We don't know, however, how much vegetation is necessary for the response, if more vegetation would reduce it further, or if certain placements or types of vegetation would be more effective than others. Education is also important if we are to use plants effectively for the benefit of humanity. Horticulture students and the horticultural industry must be educated about these benefits so that they will understand the value of what plants contribute. They will be able to justify the costs associated with using plants if they understand the economics of the returns of the investment. For example, if office complexes have higher occupancy rates when surrounded by pleasant, vegetated spaces, then the paybacks that will accrue can be calculated. Horticulturists are not the only ones who need to understand these benefits - when government officials, business leaders, and consumers appreciate the problems that can be solved with plants, demand for our products and services will grow. Extension and outreach will make this possible. If community leaders learn that planting shade trees around sports fields will not just beautify the area, but also cool the participants, reduce dust in the air that the athletes breathe, and even lower the rate of skin cancers in their sports-minded children by blocking ultraviolet sunrays, then they are more likely to budget for the installation and maintenance of trees.

Concerns over the fact that almost half of the people in the entire world now live in urban areas, places that traditionally have been largely void of plants, are increasingly being voiced as people begin to understand what we may be losing as human beings. Plants in our cities have a humanizing effect. Opportunities abound for expanding the uses and contacts that people have with plants and nature.

A change in the premise from growing crops for food or fiber to growing them for human health is having tremendous impact on changing plant biotechnology and medicine (Raskin et al., 2002). In the same way, an understanding of the connection between ornamental plants and mental, social, and environmental health rather than aesthetics is altering how we look at the value of plants and the uses that we will make of them.

\section{Literature Cited}

Agricultural Marketing Services. 2003. National organic program. 20 Apr. 2003. $<$ http://www.ams.usda.gov/nop/indexIE.htm>.

ALCA. 2001. Plants at work. 18 Apr. 2003. <http://plantsatwork.org>

American Horticultural Therapy Association. 2003. The American Horticultural Therapy Association. 18 Apr. 2003. <http://www.ahta.org>.

Amundsen, D., D. Drost, and W. Varga. 1997. Utah's Davis County Master Gardener Program. HortTechnology 7:354-356.

Anderson, N.O. and J.D. Walker. 2003. Effectiveness of web-based versus live plant identification tests. HortTechnology 13:190-195.

ANLA. 2002. About the industry. 18 Apr. 2003. <http://www.anla.org/ industry>.

ASHS. 1970. Proceedings of the symposium Horticultural Education held at Washington State University, Pullman, Wash., 20 Aug. 1969. HortScience 5:493-507.

Ballinger, W.E. 1980. Agricultural and horticultural education in the 1980s. HortScience 15:456-457.

Beckett, K.P., P.H. Freer-Smith, and G. Taylor. 2000. Particulate pollution capture by urban trees: Effect of species and windspeed. Global Change Biol. 6:995-1003.

Behe, B. and S. Barton. 2000. Consumer perceptions of product and service quality attributes in six U.S. states. J. Env. Hort. 18(2):71-78.

Behe, B., R.Nelson, S. Barton, C. Hall, C.D. Safley, S.Turner. 1999. Consumer preferences for geranium flower color, leaf variegation, and price. HortScience 34(4):740-742.

Behe, B., T.A. Prince, and H.K. Tayama. 1992. Analysis of consumer purchases of floral products in supermarkets. HortScience 27:455-459.

Bennett, E.S. and J.E. Swasey. 1996. Perceived stress reduction in urban public gardens. HortTechnology 6:125-128.

Berghage, R.D. and N.K. Lownds. 1991. Using writing in horticultural education. HortTechnology 1:124-126.

Blair, D., C. C. Giesecke, and S. Sherman. 1991. A dietary, social, and economic evaluation of the Philadelphia urban gardening project. J. Nutr. Ed. 23:161-167.

Bobbitt, V. 1997. The Washington State University Master Gardener program: Cultivating plants, people, and communities for 25 years. HortTechnology 7:345-347.

Bradley, E.L. 1999. Short-term intensive probation horticultural education programs for juvenile offenders, Norfolk, Virginia, p. 30 (abstr.). In: M. Burchett (ed.). Towards a new millennium in people-plant relationships. Univ. Technol., Sydney, Australia.

Brogan, D.R. and J.L. Douglas. 1980. Physical environment correlates of psychosocial health among urban residents. Amer. J. Commun. Psychol. 8:507-522.

Browne, C.A. 1992. The role of nature for the promotion of well being of the elderly, p. 75-79. In: D. Relf (ed.). The role of horticulture in human well-being and social development: A national symposium. Timber Press, Portland, Ore.

Bruhn, S. 1999. Texas greenhouse becomes popular tourist attraction. GrowerTalks 62:28-32. 
Bunn, D.E. 1986. Group cohesiveness is enhanced as children engage in plant stimulated discovery activities. J. Therapeutic Hort. 1:37-43.

Burchett, M., J. Tarran, and R. Wood (ed.). 1999. Towards a new millennium in people-plant relationships. Univ. Technol., Sydney, Australia.

Burlingame, A. 1974. Hoe for health: Guidelines for successful horticultural therapy programs. Mich. Garden Consultants, Birmingham.

Butler, L.M. and D.M. Maronek. 2002. Urban and agricultural communities: Opportunities for common ground. Council Agr. Sci. Technol., Ames, Iowa, Task Force Rpt. 138.

Butterfield, B. 2000. National gardening survey 1999-2000. Natl. Gardening Assn., S. Burlington, Vt.

Campbell, A.N., T.M. Waliczek, J.C. Bradley, J.M. Zajicek, and C.D. Townsend 1997. The influence of activity-based environmental instruction on high school students' environmental attitudes. HortTechnology 7:309.

Carpenter, E.D. 1972. Undergraduate students as teaching assistants in horticulture. HortScience 1:55.

Cavaliere, D. 1987. How zucchini won 5th-grade hearts. Children Today 16(3): $18-21$.

Chicago Botanic Garden. 2003. Horticultural therapy. 20 Apr. 2003. <http: //www.chicagobotanic.org/therapy/>

Cimprich, B. 1993. Development of an intervention to restore attention in cancer patients. Cancer Nursing 16:83-92.

Coder, K.D. 1996. Identified benefits of community trees and forests. 13 Mar. 2003.<http://www.forestry.uga.edu/warnell/service/library/index.php3?doc $\mathrm{ID}=124 \&$ docHistory $\% 5 \mathrm{~B} \% 5 \mathrm{D}=2>$.

Coley, R.L., F.E. Kuo, and W.C. Sullivan. 1997. Where does community grow? The social context created by nature in urban public housing. Environ. Behavior 29:468-492.

Craker, E. and Z. Gardner. 2003a. Dietary supplements: The new herbalism. HortTechnology 13:239-242

Craker, E. and Z. Gardner. 2003b. Recognition of fruit and vegetables as healthful: vitamins and phytonutrients. HortTechnology 13:252-258.

Darlington, A.B., J.F. Dat, and M.A. Dixon. 2001. The biofiltration of indoor air: air flux and temperature influences the removal of toluene, ethylbenzene, and xylene. Environ. Sci. Technol. 35:240-246.

Dawson, C.S. and J.M. Zajicek. 1999. The Green Brigade: The effects of community-based program on attitudes and behaviours of juvenile offenders, p. 384-394. In: M. Burchett, J. Tarran, and R. Wood (ed.). Towards a new millennium in people-plant relationships. Univ. Technol., Sydney, Australia.

DeHart-Bennett, M. and P.D. Relf. 1990a. Employer's perceptions of employees with mental retardation in the horticulture industry. HortScience 24 477-479.

DeHart-Bennett, M.E. and P.D. Relf. 1990b. Horticultural careers for persons with mental retardation. J. Vocatl. Spec. Needs Educ. 12(3):11-15.

DeMarco, L.W., D. Relf, and A. McDaniel. 1999. Integrating gardening into the elementary school curriculum. HortTechnology 9:276-281.

DiNicola, A., D.J. Jones, and G. Gray. 1997. Asia-Pacific forestry sector outlook study: Opportunities for forestry investment in Asia and the Pacific through carbon offset initiatives. Working Paper APFSOS/WP/29. FAO For. Policy and Planning Division, Rome.

Dobbs, G.S. and P.D. Relf. 1991. Enclave employment of disabled individuals in a university grounds maintenance department: A case study. J. Therapeutic Hort. 6:38-49.

Dobbs, K., D. Relf, and A. McDaniel. 1998. Survey on the needs of elementary education teachers to enhance the use of horticulture or gardening in the classroom. HortTechnology 8:370-373.

Dombrow, J., M. Rodriguez, and C.F. Sirmans. 2000. The market value of mature trees in single-family housing markets. Appraisal J. 68:39-43.

Dorn, S., Relf, P.D., M. Aveni, and L.F. Hartung. 1996. The Water-wise Gardener. 18 Apr. 2003. <http://www.ext.vt.edu/pubs/waterquality/ waterwise.html>

Dorn, S. and P.D. Relf. 2001. Assessing the Virginia Cooperative Extension Master Gardener Coordinator Manual. HortTechnology 11:472-476.

Downing, M. and R.K. Roberts. 1991. Estimating visitor use-value of arboreta: The case of the University of Tennessee Arboretum. J. Environ. Hort. 9 207-210.

Doxon, L.E., R.H. Mattson, and A.P. Jurich. 1987. Human stress reduction through horticultural vocational training. HortScience 22:655-656.

Eastman, L. 1999. Norfolk Botanical Gardens learning programs for 'at-risk' youth, p. 30 (abstr.). In: M. Burchett (ed.). Towards a new millennium in people-plant relationships. Univ. Technol., Sydney, Australia.

Evans, M.R. and H. Malone. 1992. People and plants: A case study in the hotel industry, p. 220 In: D. Relf (ed.). The role of horticulture in human well-being and social development: A national symposium. Timber Press, Portland, Ore

Feenstra, G., S. McGrew, and D. Campbell. 1999. Entrepreneurial community gardens: Growing food, skills, jobs and communities. Agr. Natural Resour.
Publ. 21587. Univ. Calif., Davis.

Finch, C. R. 1997. Profile of an active Master Gardener chapter. HortTechnology 7:371-376.

Fjeld, T. 2000. The effect of interior planting on health and discomfort among workers and school children. HortTechnology 10:46-52.

Flagler, J. 1992. Master Gardeners and horticultural therapy. HortTechnology $2 \cdot 249-250$.

Flagler, J. 1993. Correctional youth and the green industry. J. Therapeutic Hort. 7: 49-55.

Flagler, J. 1995. The role of horticulture in training correctional youth. HortTechnology 5:185-187.

Flagler, J. and R.P. Poincelot (eds.). 1994. People-plant relationships: Setting research priorities. Food Products Press, Binghamton, N.Y.

Francis, M., P. Lindsey, and J.S. Rice (eds.). 1994. The healing dimensions of people-plant relations. Ctr. Design Res., Univ. Calif., Davis

Fried, M. 1982. Residential attachment: Sources of residential and community satisfaction. J. Soc. Sci. 38:107-119.

Friends Hospital, 2003. Healing with plants: The wonders of horticultural therapy. 20 Apr. 2003.< http://www.friendshospitalonline.org/hortherapy.htm>.

Frumkin, H. 2001. Beyond toxicity: Human health and the natural environment. Amer. J. Prev. Med. 20:234-240.

Garber, M.P. and K. Bondari. 1992. Landscape architects as related to the landscape/nursery industry: I. Impact on demand for plant material. J. Environ. Hort. 10(2):69-72

Garber, M.P. and K. Bondari. 1995. Landscape installation firms: I. Business characteristics and trends affecting industry performance. J. Environ. Hort. 13(1):31-34.

Garber, M.P. and K. Bondari. 1996. Landscape maintenance firms: I. Business features and factors influencing industry performance. J. Environ. Hort. 14(2):53-57.

Garber, M.P. and K. Bondari. 1998. Retail garden outlets: business characteristics and factors affecting industry performance. J. Environ. Hort. 16(1): $15-19$.

Gerlach-Spriggs, N., R.E. Kaufman, and S.B. Warner. 1998. Restorative gardens: the healing landscape. Yale Univ. Press, New Haven, Conn.

Getz, D. A., A. Karow, and J. J. Kielbaso. 1982. Inner city preferences for trees and urban forestry programs. J. Arboricult. 8:258-263.

Goldsteen, J.B. 1989. What fills an office building? Its neighborhood or its design? Urban Land 55(4):2-5.

Grieshop, J.I. 1984. Serendipity and community development: a study of unplanned community development consequences in a community service program. J. Community Dev. Soc. 15(2):87-103.

Hamilton, S.L. and K. DeMarrais. 2001. Visits to public gardens: Their meaning for avid gardeners. HortTechnology 11:209-215

Hefley, D. (P.D. Relf). 1973a. Horticulture: A therapeutic tool. J. Rehab. 39(1): 27-29.

Hefley, D. (P.D. Relf) and A. Sperling. 1973b. Therapeutic recreation through horticulture. Therapeutic Rec. J. 8(3):31-34.

Henry, M.S. 1994. The contribution of landscaping to the price of single family houses: A study of home sales in Greenville, South Carolina. J. Environ. Hort. 12:65-70

Hewson, M.L.. 1994. Horticulture as therapy. Greenmor Printing Co. Ltd., Guelph, Ontario.

Hill, C.O. and P.D. Relf. 1982. Gardening as an outdoor activity in geriatric institutions. Activities, Adaptations and Aging 3(1):47-54

Holden Arboretum. 2003. Horticultural therapy program. 20 Apr. 2003. <http: //www.holdenarb.org/hortth.htm>

Holford, P., R. Ellis, and A. Haigh. 2001. The writing portfolio as a tool for the development of communication and learning skills. HortTechnology $11: 668-673$

Janick, J. 2003. Herbals: The connection between horticulture and medicine. HortTechnology 13:229-238.

Jarrott, S., H.R.Kwack and P. D. Relf. 2002. An observational assessment of a dementia-specific horticultural therapy program. HortTechnology 12: 403-409.

Jo, H.K. and E.G. McPherson. 2001. Indirect carbon reduction by residential vegetation and planting strategies in Chicago, USA. J. Environ. Mgt. 61 $165-177$.

Kaplan, R. 1973. Some psychological benefits of gardening. Environ. Behavior 5:145-162.

Kaplan, R. and S. Kaplan. 1989. The experience of nature: A psychological perspective. Cambridge Univ. Press, New York

Kaplan, S., J.F. Talbot, and R. Kaplan. 1988. Coping with daily hassles: The impact of nearby nature on the work environment. Proj. Rpt. Urban For Unit Coop. Agreement 23-85-08. N. Central For. Expt. Sta., For. Serv., USDA, St. Paul, Minn.

Kavanagh, J.S. and N. Chambers. 1995. The children's playground project at the Howard A. Rusk Institute for Rehabilitation Medicine. Child Health 
Design 9:19.

Kerrigan, J. and N.C. Stevenson. 1997. Behavioral study of youth and elders in an intergenerational horticultural therapy program, p. 141-154. In: S.E. Wells (ed.). Horticultural therapy and the older adult population. Haworth Press, Binghamton, N.Y.

Kohlleppel, T., J.C. Bradley, and S. Jacob. 2002. A walk through the garden: Can a visit to a botanic garden reduce stress? HortTechnology 12:489-491.

Kuo, F.E. and W.C. Sullivan. 1996. Do trees strengthen urban communities, reduce domestic violence? For. Rpt. R8-FR 55, Tech. Bul. No. 4. USDA For. Serv. S. Reg., Athens, Ga.

Kuo, F.E. and W.C. Sullivan. 2001. Environment and crime in the inner city: Does vegetation reduce crime? Environ. Behavior 33:343-367.

Kuo, F.E., W.C. Sullivan, R.L. Coley, and L. Brunson. 1998. Fertile ground for community: Inner-city neighborhood common spaces. Amer. J. Community Psychol. 26:823-851.

Kweon, B.S., W.C. Sullivan, and A. Wiley. 1998. Green common spaces and the social integration of inner-city older adults. Environ. Behavior 30: 832-858.

Lawrence, G.M. 1900. Principles of education for the feeble minded. J. PsychoAesthenics 4(3):100-108.

Lineberger, S.E. 1999. The effect of school gardens on children's attitudes and related behaviors regarding fruits and vegetables. 13 Mar. 2003. <http: //aggie-horticulture.tamu.edu/nutrition/research/abstract.html>

Littman, M. 1996. Green city: Gardening and urban agriculture resources. The Neighborhood Works 19(3).

Lobo, R.E., G.E. Goldman, D.A. Jolley, B.D. Wallace, W.L. Schrader, and S.A. Parker. 1999. Agritourism benefits agriculture in San Diego County. Calif. Agr. 53:20-24.

Lockwood, I.M. and T. Stillings. 2001. Traffic calming for crime reduction and neighborhood revitalization. 20 Apr. 2003. <http://www.ite.org/traffic/ documents/AHA98A19.pdf>.

Lohr, V.I. 1992a. Research on human issues in horticulture motivates students to learn science. HortTechnology 2:257-259.

Lohr, V.I. 1992b. The contribution of interior plants to relative humidity in an office, p. 117-119. In: D. Relf (ed.). The role of horticulture in human wellbeing and social development. Timber Press, Portland, Ore.

Lohr, V.I. 2000. International human issues in horticulture. HortTechnology 10:12-93.

Lohr, V.I. and D.J. Cotter. 1984. Are introductory courses effective? NACTA J. 28(1):32-35.

Lohr, V.I. and C.H. Pearson-Mims. 1996. Particulate matter accumulation on horizontal surfaces in interiors: Influence of foliage plants. Atmos. Environ. 30:2565-2568.

Lohr, V.I. and C.H. Pearson-Mims. 2000. Physical discomfort may be reduced in the presence of interior plants. HortTechnology 10:53-58.

Lohr, V.I. and C.H. Pearson-Mims. 2002. Childhood contact with nature influences adult attitudes and actions towards trees and gardening, p. 267-277. In: C.A. Shoemaker (ed.). International interaction by design: Bringing people and plants together for health and well-being: An international symposium. Iowa State Press, Ames.

Lohr, V.I., C.H. Pearson-Mims, and G.K. Goodwin. 1996. Interior plants may improve worker productivity and reduce stress in a windowless environment. J. Environ. Hort. 14:97-100.

Lohr, V.I. and P.D. Relf. 2000. An overview of the current state of human issues in horticulture in the United States. HortTechnology 10:27-33.

Macpherson, M. 1993. Benefits of urban greening. Merck Family Fund, Milton, Mass.

Malakoff, D. 1995. What good is community greening? American Community Gardening Assn. Monogr. Pa. Hort. Soc., Philadelphia.

Marcus, C.C. and M. Barnes. 1999. Healing gardens: Therapeutic benefits and design recommendations. Wiley, New York.

Matsuo, E. 1995. Horticulture helps us to live as human beings: Providing balance and harmony in our behavior and thought and life worth living. Acta Hort. 391:19-30.

Mattson, R.H. 1992. Prescribing health benefits through horticultural activities In: D. Relf (ed.). The role of horticulture in human well-being and social development. Timber Press, Portland, Ore..

Mattson, R.H. and R.T. Hilbert. 1976. Psychological, social, physical and educational effects of horticultural therapy for geriatrics. HortScience 11:328.

McCandliss, R. 1967. The plant/man/environment. Paper presented at C.F. Menninger Memorial Hospital Staff Mtg., Topeka, Kan.

McGuinn, C. and P.D. Relf. 2001. A profile of juvenile offenders in a vocational horticulture curriculum. HortTechnology 11:427-432.

Meyer, M.H. 1997. Master Gardener projects - Making connections. HortTechnology 7:339-344.

Michelfelder, D.P. 2003. Valuing wildlife populations in urban environments. J. Soc. Philos. 34:79-90.

Monterusso, M.A., D.B. Rowe, and C.L. Rugh. 2002. Runoff water quantity and quality from green roof systems. XXVIth Intl. Hort. Congr. On-Site Progr. (abstract S07-P-31).

Mooney, P.F. 1994. Assessing the benefits of a therapeutic horticulture program for seniors in immediate care, p. 173-194. In: M. Francis, P. Lindsey, and J.S. Rice (eds.). The healing dimensions of people-plant relations. Ctr. Design Res., Davis, Calif.

Mooney, P.F. and P.L. Nicell. 1992. The importance of exterior environment for Alzheimer's residents: Effective care and risk management. Healthcare Mgt. Forum 5(2):23-29.

Namazi, K.H. and S.R. Haynes. 1994. Sensory stimuli reminiscence for patients with Alzheimer's disease: Relevance and implications. Clin. Gerontol. 14(4): 29-45

Palaniswamy, U.R. 2003. Vegetarianism and human health. HortTechnology 13: $243-251$

Parsons, R., L.G. Tassinary, R.S. Ulrich, M.R. Hebl, and M. Grossman-Alexander. 1998. The view from the road: Implications for stress recovery and immunization. J. Environ. Psychol. 18:113-140.

Patel, I.C. 1992. Socio-economic impact of community gardening in an urban setting, p. 84-87. In: D. Relf (ed.). The role of horticulture in human wellbeing and social development Timber Press, Portland, Ore.

Plants for People. 2002. Science. 18Apr. 2003. <http://www.plants-for-people.org/ eng/science/f.htm>.

Pothukuchi, K. and J. Bickes. 2001. Youth nutrition gardens in Detroit: A report on benefits, potential, and challenges. Wayne State Univ., Detroit, Mich.

Predny, M. and P.D. Relf. 2000. Interactions between elderly adults and preschool children in a horticultural therapy research program. HortTechnology 10: 64-70.

Quebedeaux, B. andF.A. Bliss. 1988. Horticulture and human health: Contributions of fruits and vegetables. Prentice Hall, Englewood Cliffs, N.J.

Raskin, I., D.M. Ribnicky, S. Komarnytsky, N. Ilic, A. Poulev, N. Borisjuk, A.Brinker, D.A. Moreno, C. Ripoll, N.Yakoby, J.M. O’Neal, T. Cornwell, I. Pastor and B. Fridlender. 2002, Plants and human health in the twenty-first century [review]. Trends Biotechnol. 20(12):522-531.

Read, PaulE. 2003. Introduction (to the proceedings of the workshop on the history of horticulture and human health). HortTechnology 13:226-228.

Relf, P.D. 1978. Horticulture as a recreational activity. Amer. Health Care Assn. J. 4(5):68-71.

Relf, P.D. 1981a. The use of horticulture in vocational rehabilitation. J. Rehab. 47(3):53-56.

Relf, P.D. 1981b. Dynamics of horticultural therapy. Rehab. Lit. 42:147-150.

Relf, D. 1992a. Human issues in horticulture. HortTechnology 2:159-189,201-206, 236-238, 244-259, 284-287.

Relf, D. 1995. Horticulture meeting special needs. HortTechnology 2:94-121,131141,171-174, 182-187.

Relf, D. (ed.). 1992b. The role of horticulture in human well-being and social development. Timber Press, Portland, Ore.

Relf, P.D., A.R. McDaniel, and D. Chaves. 1982. Horticulture in provocation training for EMR students. J. Voc. Spec. Needs Educ. 4(2):20-21, 25, 32.

Relf, D., A.R. McDaniel, and B. Butterfield. 1992. Attitudes toward plants and gardening. HortTechnology 2:201-204.

Relf, P.D. and S.T. Dorn. 1995. Horticulture: Meeting the needs of special populations. HortTechnology 5(3):94-103.

Ruppert, K.C., J. Bradshaw, and A.Z. Stewart. 1997. The Florida Master Gardener Program: History, use, and trends. HortTechnology 7:348-353.

Rusk Institute of Rehab Medcine. 2003. Enid Haupt glasshouse. 20 Apr. 2003. $<$ http://www.ruskinstitute.org/ri/rusk/rusk_gg_therapy.jsp >.

Sailor, D.J. 1998. Simulations of annual degree day impacts of urban vegetation augmentation. Atmos. Environ. 32:43-52.

Schrock, D.S., M. Meyer, P. Ascher, and M. Snyder. 2000. Reasons for becoming involved as a Master Gardener. HortTechnology 10:626-630.

Shoemaker, J. and R.H. Mattson. 1982. Defining horticulture as a therapeutic modality. Part 1: Profiles in horticultural therapy, Part 2: Models in horticultural therapy. Kan. State Univ., Manhattan.

Shoemaker, C.A.(ed.) 2002. Interaction by design: Bringing people and plants together for health and well-being: An international symposium. Iowa State Press, Ames.

Shoemaker, C.A., P.D. Relf, and V.I. Lohr. 2000. Social science methodologies for studying individual's responses in human issues in horticulture research. HortTechnology 10:87-93.

Skelly, S.M. and J.M. Zajicek. 1998. The effect of an interdisciplinary garden program on the environmental attitudes of elementary school students. HortTechnology 8:579-583.

Steavenson, H., P.L. Smeal, and G. Long. 1975. Horticultural education-Does it fall short of the mark? Comb. Proc. Int. Plant Prop. Soc. p. 429-441.

Talbott, J.A., D. Stern, J. Ross, and C. Gillen. 1976. Flowering plants as a therapeutic/environmental agent in a psychiatric hospital. HortScience 11: 365-366.

Taylor,A.F., F.E. Kuo, and W.C. Sullivan. 2001. Coping withADD: The surprising 
connection to green play settings. Environ. Behavior 33:54-77.

Taylor, A.F., A. Wiley, F.E. Kuo, and W.C. Sullivan. 1998. Growing up in the inner city: Green spaces as places to grow. Environ. Behavior 30:3-27.

Taylor, M. K. 1990. The healthy gardener. Flower Garden (March/April): 46-47.

Templeton, S.R., C. Brown, G.E. Goldman, S.J. Yoo, and V.S. Pradhan. 2000. An economic analysis of environmental horticulture with a focus on California. HortScience 35:987-992.

Tennessen, C.M. and B. Cimprich. 1995. Views to nature: Effects on attention. J. Environ. Psychol. 15:77-85.

Turner, L.W., M.A. Bass, L. Ting, and B. Brown. 2002. Influence of yard work and weight training on bone mineral density among older U. S. women. J. Women Aging 14(3-4):139-148.

Tyrväinen, L. 2001. Economic valuation of urban forest benefits in Finland. J. Environ. Mgt. 62:75-92.

Ulrich, R. S. 1984. View through a window may influence recovery from surgery. Science 224:420-421.

Ulrich, R. S. and R. F. Simons. 1986. Recovery from stress during exposure to everyday outdoor environments. p. 115-122. In: J. Wineman, R. Barnes, and C. Zimring (eds.). The Costs of Not Knowing. Proc. 17th Annual Conference of the Environmental Research and Design Association, Washington, D.C.

VAMedical Center, Salem, Virginia. 2003. Psychology staff. 20 Apr. 2003. <http: //www.avapl.org/training/Salem/staff.htm>.

Waliczek, T.M., R.H. Mattson, and J.M. Zajicek. 1996. Benefits of community gardening to quality of life issues. J. Environ. Hort. 14:204-209.

Waliczek, T.M. and J.M. Zajicek. 1999. School gardening: Improving environmental attitudes of children through hands-on learning. J. Environ. Hort. 17: $180-184$.

Watson, D.P. and Burlingame, A.W. 1960. Therapy through horticulture. MacMillian, New York.
Wells, N.M. 2000. At home with nature: Effects of "greenness" on children's cognitive functioning. Environ. Behavior 32:775-795.

White, J.W., D.J. Beattie, and P. Kubek. 1990. Inquiry learning with videodiscs and computers: an innovative teaching method for horticulture courses. HortScience 25:385-388.

Williams, P. and J. Zajicek (eds.). 1997. People-plant interactions in urban areas Dept. Hort., Texas A\&M Univ., College Station.

Wise, J.A. and E. Rosenberg. 1988. The effects of interior treatments on performance stress in three types of mental tasks. CIFR Tech. Rpt. No. 002-02-1988. Grand Valley State Univ., Grand Rapids, Mich.

Wolf, K. 1998a. Growing with green: Business districts and the urban forest. 13 Mar. 2003. < http://www.cfr.washington.edu/research.envmind/CityBiz/ BizQual-FS2.pdf>.

Wolf, K. 1998b. Trees in business districts: Positive effects on consumer behavior! 13 Mar. 2003. <http://www.cfr.washington.edu/research.envmind/CityBiz/ BizQual-FS5.pdf>.

Wolverton, B.C., A. Johnson, and K. Bounds. 1989. Interior landscape plants for indoor air pollution abatement. Final Rpt. Plants for clear air, NASA, Stennis Space Center, Miss.

Wolverton, B.C., R.C. McDonald, and E.A. Watkins, Jr. 1984. Foliage plants for removing indoor air pollutants from energy efficient homes. Econ. Bot. 38:224-228.

Wolverton, B.C. and J. Wolverton. 1993. Interior plants: Their influence on airborne microbes and relative humidity levels inside energy-efficient buildings. Research report WES/100/05-93/011, Wolverton Environ. Serv., Inc., Picayune, Miss

Wood, R.A., R.L. Orwell, J. Tarran, F. Torpy, and M. Burchett. 2002. Pottedplant/growth media interactions and capacities for removal of volatiles from indoor air. J. Hort. Sci. Biotechnol. 77:120-129. 